\title{
EFEKTIVITAS PROGRAM KELUARGA HARAPAN DALAM UPAYA PENGENTASAN KEMISKINAN DI KECAMATAN PADALARANG KABUPATEN BANDUNG BARAT
}

\author{
Felinda Wulandari ${ }^{1}$, Yamardi² $^{2}$, Titin Rohayatin ${ }^{3}$ \\ Program Studi Ilmu Pemerintahan, Fakultas Ilmu Sosial dan Ilmu Politik, \\ Universitas Jenderal Achmad Yani, Indonesia
}

\begin{abstract}
Abstrak
Penelitian ini membahas terkait Efektivitas Program Keluarga Harapan Dalam Upaya Pengentasan Kemiskinan di Kecamatan Padalarang, Kabupaten Bandung Barat. Permasalahan dalam penelitian ini yaitu belum efektifnya Program Keluarga Harapan (PKH) di Kecamatan Padalarang. Tujuan penelitian mendeskripsikan dan menganalisis pelaksanaan $\mathrm{PKH}$ pengentasan kemiskinan di Kecamatan Padalarang Kabupaten Bandung Barat. Metode penelitian deskriptif dengan pendekatan kualitatif. Teknik pengumpulan data melalui studi pustaka dan studi lapangan (wawancara, observasi, dan dokumentasi). Teknik analisis data melalui reduksi data, penyajian data dan penarikan kesimpulan. Unit analisis dan informan Dinas Sosial yaitu UPPKH Bandung Barat, Koordinator Pendamping PKH Kecamatan Padalarang, dan Peserta PKH. Hasil penelitian menunjukan bahwa Efektivitas Program Keluarga Harapan di Kecamatan Padalarang belum efektif. Terlihat belum optimalnya pemberian bantuan, dana yang diterima peserta PKH tidak sesuai dengan keadaan PKH, selain itu dana yang diterima pendamping PKH juga tidak sesuai dengan pengeluarannya, dan kurang tegasnya sanksi yang diberikan pendamping kepada peserta PKH yang tidak melaksanakan kewajibannya, masih belum tepat sasaran dalam memberikan bantuan kepada masyarakat miskin.
\end{abstract}

\section{Abstract}

This study discusses the effectiveness of the Hope Family Program in Poverty Alleviation Efforts in Padalarang District, West Bandung Regency. The problem in this research is the ineffectiveness of the Family Hope Program (PKH) in Padalarang District. The purpose of the study is to describe and analyze the implementation of poverty alleviation $\mathrm{PKH}$ in Padalarang District, West Bandung Regency. Descriptive research method with a qualitative approach. Data collection techniques through literature study and field studies (interviews, observations, and documentation). Data analysis techniques through data reduction, data presentation, and conclusion drawing. The unit of analysis and informants from the Social Service are UPPKH West Bandung, 
PKH Co-ordinating Coordinator of Padalarang District, and PKH Participants. The results showed that the effectiveness of the Hope Family Program in Padalarang District was not yet effective. It was seen that the assistance provided was not optimal, the funds received by PKH participants were not in accordance with the $\mathrm{PKH}$ situation, besides the funds received by $\mathrm{PKH}$ companions were also not in accordance with their expenditure, and the lack of sanctions imposed by the companion to PKH participants who did not carry out their obligations was still not well targeted provide assistance to the poor.

\section{PENDAHULUAN}

Kemiskinan merupakan salah satu masalah yang dihadapi Pemerintah dan Masyarakat Indonesia. Perlu adanya keselarasan antara pemerintah dan masyarakat untuk sama-sama mengatasi permasalah kemiskinan, berbagai program pemerintah sudah dilakukan tetapi pada kenyataanya tidak berjalan dengan efektif untuk menanggulangi kemiskinan. Menurut Nugroho(1995) Kemiskinan yaitu "Kondisi masyarakat yang disebut miskin dapat diketahui berdasarkan kemampuan pendapatan dalam memenuhi standar hidup".

Upaya penanggulangan kemiskinan dilakukan dengan penyedian kebutuhan dasar seperti pangan, pelayanan kesehatan, pendidikan, perluasan kesempatan kerja, pembangunan pertanian, pemberian dana bergulir melalui sistem kredit, pembangunan prasarana dan pendampingan, penyuluhan sanitasi dan sebagainya. Dari serangkaian cara dan strategi penanggulangan kemiskinan tersebut, semua berorientasi pada material, sehingga keberlanjutan sangat bergantung pada ketersediaan anggaran dan komitmen pemerintah.

Di samping itu, tidak adanya tatanan pemerintah yang demokratis menyebabkan rendahnya aksestabilitas dan inisiatif masyarakat untuk menanggulangi kemiskinan dengan cara mereka sendiri. Upaya pengetasan kemiskinan kini semakin mendesak kembali untuk dikaji ulang. Salah satu program yang merupakan kebijakan perlindungan sosial yaitu Program Keluarga Harapan (PKH). Program tersebut sebagai bentuk pembelajaran 
kepada masyarakat miskin agar dapat lebih disiplin dalam mengelola bantuan agar dirasakan menjadi lebih bermanfaat dan bertanggungjawab dalam meningkatkan kualitas pendidikan dan kesehatan.

Agar dapat mengentaskan kemiskinan bantuan yang diberikan oleh pemerintah seharusnya mampu membuat masyarakat miskin semakin mandiri dan sejahtera, bukan malah ketergantungan. Salah satu harapan untuk pelaksanaan Program Keluarga Harapan kedepannya yaitu pemerintah memasukkan program-program pemberdayaan masyarakat ke dalam program PKH Kemensos. Jika tidak didukung dengan upaya-upaya pemberdayaan, dikhawatirkan tingkat ketergantungan masyarakat terhadap bantuan PKH akan meningkat dan jumlah penerima program akan semakin banyak. Berikut adalah tabel jumlah masyarakat penerima PKH di Kabupaten Bandung Barat sejak Tahun 2017-2019:

Tabel 1 Jumlah Keluarga Penerima Manfaat PKH

NO KECAMATAN

1. Batujajar

2. Cihampelas

3. Cikalong Wetan

4. Cililin

5. Cipatat

6. Cipeundeuy

7. Cipongkor

8. Cisarua

9. Gunung Halu

10. Lembang

11. Ngamprah

12. Padalarang
KPM $2017 \quad$ KPM $2018 \quad$ KPM 2019

2093

3612

2921

4717

6893

7029

4101

4335

5605

2958

5630

1238

3037

4820

2096

3106
5996

5882

7841

4102

7188

1919

4002

6422

3640

4982
6080

5727

7857

4147

7014

1929

3945

6167

3620 


$\begin{array}{llccc}\text { 13. } & \text { Parongpong } & 1112 & 2007 & 1900 \\ \text { 14. } & \text { Rongga } & 2351 & 3814 & 3925 \\ \text { 15. } & \text { Saguling } & 1761 & 1900 & 2429 \\ \text { 16. } & \text { Sindang kerta } & 3065 & 3763 & 3677 \\ & \text { JUMLAH } & \mathbf{5 2 0 2 5} & \mathbf{7 3 9 6 3} & \mathbf{7 3 3 5 6}\end{array}$

Sumber : UPPKH Kabupaten Bandung Barat

Program Keluarga Harapan (PKH), yaitu sebuah bantuan bersyarat sebagai jaminan sosial untuk mengakses kesehatan dan pendidikan yang mencakup kesehatan balita dan ibu hamil serta pendidikan bagi anak usia pendidikan dasar. PKH lebih dimaksudkan kepada upaya membangun sistem perlindungan sosial kepada masyarakat miskin. Pelaksanaan di Indonesia diharapkan akan membantu penduduk termiskin, bagian masyarakat yang paling membutuhkan uluran tangan dari siapapun juga. Efektivitas merupakan ketepatan harapan, implementasi dan hasil yang dicapai, sedangkan kegiatan yang tidak efektif adalah kegiatan yang selalu mengalami kesenjangan antara harapan, implementasi dengan hasil yang dicapai (Makmur, 2015). Peneliti menggunakan teori dari (Makmur, 2015), unsurunsur efektivitas antara lain:

a. Ketepatan penentuan waktu

b. Ketetapan perhitungan

c. Ketepatan dalam pengukuran

d. Ketepatan dalam penentuan pilihan

e. Ketepatan berpikir

f. Ketepatan dalam melakukan perintah

g. Ketepatan Menentukan tujuan

h. Ketepatan sasaran

Dari uraian di atas, sesuai dengan permasalahan yang akan dibahas oleh peneliti, mengenai Efektivitas Program Keluarga Harapan dalam Upaya 
Pengentasan Kemiskinan di Kecamatan Padalarang, karena dilihat dari Program Keluarga Harapan belum efektifnya program tersebut.

\section{METODE PENELITIAN}

Penelitian ini menggunakan metode deskriptif kualitatif. David Williams (dalam Moleong, 2007) mendefinisikan penelitian kualitatif adalah: "Pengumpulan data pada suatu latar ilmiah, dengan menggunakan metode alamiah dan dilakukan oleh orang atau peneliti yang tertarik secara ilmiah". Penelitian ini dilakukan di Kecamatan Padalarang Kabupaten Bandung Barat. Pengumpulan data dalam penelitian ini menggunakan beberapa teknik, seperti wawancara, observasi, dokumentasi dan studi pustaka. Adapun informan dalam penelitian ini antara lain, Kepala Unit Pelaksana PKH di Kabupaten Bandung Barat, Koordinator pendamping PKH Kecamatan Padalarang, dan Peserta PKH.

\section{HASIL DAN PEMBAHASAN}

Efektivitas yaitu suatu ukuran yang menyatakan seberapa jauh target (kuantitas,kualitas dan waktu) yang telah dicapai oleh manajemen, dalam target tersebut sudah ditentukan terlebih dahulu. Upaya mengevaluasi jalannya suatu organisasi dapat dilakukan melalui konsep efektivitas.

Menurut (Handayaningrat, 1994) efektivitas adalah pengukuran dalam arti tercapainya tujuan yang telah ditentukan sebelumnya. Sedangkan menurut (Kurniawan, 2005) efektivitas adalah kemampuan melaksanakan tugas, fungsi (operasi kegiatan program atau misi) daripada suatu organisasi atau sejenisnya yang tidak adanya tekanan atau ketegangan diantara pelaksanaannya. 
Konsep efektivitas ini adalah salah satu faktor untuk menenetukan apakah perlu dilakukan perubahan secara signifikan terhadap bentuk dan manajemen organisasi atau tidak. Dalam hal ini efektivitas merupakan pencapaian tujuan organisasi dengan cara pemanfaatan sumber daya yang dimiliki secara efisien, ditinjau dari sisi masukan (input), Proses maupun keluaran (output).

Dalam hal ini yang dimaksud sumber daya meliputi ketersediaan personil, sarana dan prasarana serta metode dan model yang digunakan. Dalam suatu kegiatan dikatakan efisien apabila dikerjakan dengan benar dan sesuai dengan prosedur sedangkan dikatakan efektif bila kegiatan tersebut dilaksanakan dengan benar dan memberikan hasil yang bermanfaat. Dalam hal ini dilihat dari sudut pandang teoritis keilmuan yang sesuai dengan analisis dan penelitian yang telah peneliti lakukan dengan menggunakan teori (Makmur, 2015), yang menyatakan bahwa Efektivitas dapat dilihat dari delapan dimensi yaitu:

\section{Ketepatan Waktu}

Ketepatan waktu pada hakikatnya merupakan sesuatu yang dapat menentukan keberhasilan dari pelaksanaan suatu program atau kegiatan. Penggunaan waktu yang tepat akan menciptakan efektivitas pencapaian tujuan yang telah ditetapkan sebelumnya. Berdasarkan hasil wawancara dengan Kepala UPPKH Kabupaten Bandung Barat, Kepala Koordinator Pendamping PKH Kecamatan Padaralarng dan Peserta PKH pada bulan Februari 2020, Ketepatan waktu dalam hal pencairan dana dilaksanakan 4 periode yaitu di bulan Januari, Mei, Agustus, Oktober. Namun dalam teknis di lapangan pencairannya terkadang tidak tepat waktu, lebih cepat atau lebih lambat.

Dengan demikian dalam hal pencairan dana ini, waktunya berubah-ubah sesuai dengan pencairan dana dari pusat. Jadi apabila ada keterlambatan itu terjadi karena memang dari pemerintah pusat yang lambat dalam pencairan 
dana kepada peserta PKH. Pemerintah Kecamatan Padalarang dalam pelaksanaannya sudah menjalankan tugasnya dengan baik, karena keterlambatan pemberian bantuan dana kepada peserta PKH disebabkan lambatnya bantuan dari pusat, dan hal ini mengakibatkan keterlambatan dalam memberikan bantuan.

\section{Ketepatan Penghitungan Biaya}

Dalam pelaksanaan suatu program, ketepatan dalam penghitungan biaya tentu saja sangat diperlukan. Berdasarkan hasil wawancara dengan Kepala UPPKH Kabupaten Bandung Barat, Kepala Koordinator Pendamping PKH Kecamatan Padalarang dan Peserta PKH pada bulan Februari 2020, dana yang diterima oleh peserta PKH sesuai dengan komponen. Untuk Komponen SD sebesar 225.000, untuk Komponen SMP sebesar 325.000, Untuk komponen SMA sebesar 500.000, untuk komponen balita sebesar 600.000, dan untuk balita sebesar 750.000. Dana tersebut diberikan sesuai dengan komponen dan diberikan nya per pencairan kepada peserta $\mathrm{PKH}$.

Namun, disisi yang lain dana yang diterima oleh para pendamping PKH tidak sesuai dengan pengeluaran yang harus dikeluarkan dalam melaksanakan tugas sebagai pendamping PKH. Seharusnya, pemerintah lebih memerhatikan pengeluaran para pendamping dalam melaksanakan tugasnya sehingga terjadi kesesuaian antara dana yang diterima dengan dana yang harus dikeluarkan dalam melaksanakan tugas sebagai pendamping PKH.

Sedangkan dalam hal efisiensi dana yang digunakan oleh peserta PKH cukup efisien, karena dana yang ada digunakan sesuai dengan keperluan masing-masing keluarga. Jika komponen balita diusahakan membeli keperluan makanan bergizi untuk anaknya, apabila komponen sekolah diusahakan untuk keperluan sekolah anak, dan apabila komponen lanjut usia untuk pemeriksaan kesehatan. Dalam penggunaan dana yang ada, peserta mendapatkan pendampingan, arahan, serta motivasi oleh Pendamping RTSM 
sehingga dana yang ada memang digunakan sesuai dengan kebutuhan yang ada.

\section{Ketepatan Dalam Pengukuran}

Tujuan umum dari PKH yakni mengurangi kemiskinan, dalam jangka pendek $\mathrm{PKH}$ diharapkan dapat membantu beban pengeluaran masyarakat miskin dalam memenuhi kebutuhan dasarnya akan akses kesehatan serta akses pendidikan, dan dalam jangka panjang diharapkan mampu memutuskan rantai kemiskinan antar generasi.

Berdasarkan hasil wawancara dengan Kepala UPPKH Kabupaten Bandung Barat, Kepala Koordinator Pendamping PKH Kecamatan Padalarang dan Peserta PKH pada bulan Februari 2020, keberhasilan PKH dapat dilihat dari tingkat kehadiran RTSM peserta PKH pada aspek pendidikan dan aspek kesehatan. Dalam hal ini, pendamping wajib memantau setiap kehadiran para peserta PKH sebagai salah satu kewajiban nya sebagaimana persyaratan sebagai peserta $\mathrm{PKH}$. PKH harus mampu meningkatkan taraf hidup RTSM peserta PKH agar kedepannya mereka mampu memenuhi kebutuhan dasarnya sendiri tanpa terus bergantung pada bantuan dari pemerintah.

Pelaksanaan PKH di Kecamatan Padalarang telah sesuai dengan salah satu tujuan $\mathrm{PKH}$, yakni mengurangi beban pengeluaran masyarakat miskin peserta $\mathrm{PKH}$, dan untuk meningkatkan nilai tambah ekonomi, program ini memberikan motivasi serta pelatihan bagaimana maemanfaatkan potensi yang ada dalam diri peserta PKH sesuai dengan potensi diri masing-masing melalui Program Peningkatan Kemampuan Keluarga, di dalam P2K2 peserta PKH diberikan pembekalan mengenai pendidikan anak, pengelolaan keuangan, kesehatan ibu dan anak, kekerasan terhadap anak dan sebagainya. PKH di Kecamatan Padalarang telah mencapai tujuan yakni memutuskan rantai kemiskinan melalui bantuan dari PKH dan masyarakat menggunakan dana $\mathrm{PKH}$ dengan membuat usaha-usahanya sendiri agar mereka tidak terus bergantung kepada bantuan tersebut. 


\section{Ketepatan Dalam Menentukan Pilihan}

Ketepatan dalam menentukan pilihan dilihat dari ketepatan dalam memilih SDM sebagai pelaksana PKH. Pendamping PKH merupakan salah satu unsur penting dalam pelaksanaan $\mathrm{PKH}$, karena pendamping merupakan unsur yang berhubungan dengan RTSM peserta PKH. pendamping haruslah sumber daya manusia yang berkualitas yang mampu menjalankan tugasnya. Peran pendamping dalam pelaksanaan sangatlah diperlukan, karena pendamping merupakan orang yang berhubungan langsung dengan peserta PKH dan sebagai fasilitator yang menyampaikan informasi dari pusat kepada RTSM peserta PKH. Pendamping sangatlah dibutuhkan demi tercapainya tujuan dari PKH itu sendiri.

Berdasarkan hasil wawancara dengan Kepala UPPKH Kabupaten Bandung Barat dan Kepala Koordinator Pendamping PKH Kecamatan Padalarang pada bulan Februari 2020, para pendamping PKH di Kecamatan Padalarang sudah mempuni karena pendamping PKH berpendidikan S-1 (Sarjana) dan D-3 (Diploma). Pedamping PKH mempunyai wawasan dan pendidikan yang tinggi, sehingga kualitas SDM sangat berpengaruh kepada monitoring peserta PKH. pendamping PKH di Kecamatan Padalarang sudah terseleksi walaupun pendidikannya berbeda-beda tetapi menjalankan tugas sebagai pendamping PKH sudah cukup baik, karena berasal dari sumber daya manusia yang telah di seleksi serta melaksanakan Diklat khusus sebagai pendamping $\mathrm{PKH}$.

\section{Ketepatan Berpikir}

Ketepatan berpikir dilihat dalam hal Ketepatan menentukan pihak yang berperan dalam pelaksanaan PKH. Suatu kegiatan ataupun program bisa berjalan program bisa berjalan dengan lancar dan mampu tujuan yang diharapkan dapat diraih ketika pihak-pihak yang berperan dalam program tersebut memeliki keahlian, berkualitas serta bertanggung jawab. PKH dapat 
berjalan dengan lancar jika sumber daya manusia yang PKH menjalankannya merupakan sumber daya manusia yang berkualitas.

Berdasarkan hasil wawancara dengan Kepala UPPKH Kabupaten Bandung Barat dan Kepala Koordinator Pendamping PKH Kecamatan Padalarang pada bulan Februari 2020, peran antar pihak sudah berjalan dengan baik para pendamping PKH jika mengadakan sosialisasi menyediakan ruangan/fasilitas. Adanya pihak-pihak yang bertanggung jawab dalam pelaksanaan PKH yaitu antar UPPKH Kabupaten bandung barat dengan Koordinataor Pendamping PKH Kecamatan Padalarang.

Sedangkan dalam hal koordinasi antara Koordinator Pendamping dengan Para Pendamping PKH, pihak desa sudah dilakukan di Kecamatan Padalarang dan terjalin cukup baik dalam pelaksanaan $\mathrm{PKH}$, untuk koordinasi dengan pihak kecamatan pun terjalin dengan baik jika ada permasalahan mengenai pelaksanaan PKH dilapangan biasanya dikoordinasikan dengan pihak kecamatan.

\section{Ketepatan Dalam Melakukan Perintah}

Keberhasilan aktivitas suatu organisasi sangat banyak dipengaruhi oleh kemampuan seorang pemimpin, salah satu tuntutan kemampuan memberikan perintah yang jelas dan mudah dipahami oleh bawahan. Jika perintah yang diberikan kepada bawahan yang tidak dapat dimengerti atau dipahami, maka pelaksanaan perintah tersebut dapat dipastikan akan mengalami kesulitan dan bahkan kegagalan dalam pelaksanaan PKH adalah ketepatan dalam melakukan kewajiban sebagaimana telah di uraikan dalam pedoman umum PKH mengenai kewajiban peserta PKH serta pelaksana PKH lainnya.

Dalam hal ini pentingnya kejelasan mengenai sosialisasi tugas dan kewajiban dari peserta PKH. Sosialisasi merupakan hal yang perlu dilakukan dalam pelaksanaan $\mathrm{PKH}$, dengan adanya sosialisasi, RTSM peserta $\mathrm{PKH}$ paham akan hak dan kewajiban mereka sebagai peserta PKH. Dengan ini, maka berbagai permasalahan dapat terminimalisir. Sosialisasi PKH di tingkat 
kecamatan dilakukan oleh para pendamping PKH melakukan sosialisasi ke RTSM peserta PKH pada saat pertemuan pertama maupun pertemuan bulanan yang secara rutin dilakukan.

Berdasarkan hasil wawancara pada bulan Februari 2020 dengan Kepala UPPKH Kabupaten Bandung Barat, Kepala Koordinator Pendamping PKH Kecamatan Padalarang dan Peserta PKH sosialisasi tugas dan kewajiban peserta $\mathrm{PKH}$ telah disampaikan dengan jelas oleh pendamping $\mathrm{PKH}$ pada setiap pertemuan antar pendamping $\mathrm{PKH}$ dengan peserta $\mathrm{PKH}$ dampingnya, yakni pertemuan peningkatan kemampuan keluarga yang diadakan setiap bulannya oleh peserta PKH dengan pendamping PKH diberikan sosialisasi mengenai tugas dan kewajiban PKH dengan mendata masyarakat yang cocok menerima dan memenuhi persyaratan agar bantuan PKH tepat sasaran, maka dari itu sosialisasi sangat penting dalam pemberian bantuan PKH. Dengan demikian, sosialisasi mengenai PKH selalu disampaikan dengan jelas oleh pendamping PKH kepada peserta PKH.

\section{Ketepatan Dalam Menentukan Tujuan}

Setiap pelaksanaan sebuah program tentu saja memiliki sebuah tujuan yang ingin dicapai. Tujuan dari PKH sendiri ialah mengurangi kemiskinan, dalam jangka pendek diharapkan dapat membantu baban pengeluaran masyarakat miskin, dan dalam jangka panjang diharapkan dapat memutus rantai kemiskinan antar generasi.

Berdasarkan hasil wawancara pada bulan Februari 2020 dengan Kepala UPPKH Kabupaten Bandung Barat, Kepala Koordinator Pendamping PKH Kecamatan Padalarang dan Peserta PKH pencapaian PKH di Kecamatan Padalarang telah cukup baik, terbukti dengan meningkatnya angka partisipasi masyarakat miskin yang menjadi peserta PKH terhadap layanan kesehatan dan layanan pendidikan, PKH mewajibkan peserta PKH untuk dapat memenuhi kewajiban mereka, Contohnya yakni terdaftar serta hadir pada fasilitas pendidikan, serta hadir pada fasilitas kesehatan, dengan demikian 
kualitas pendidikan serta kesehatan masyarakat miskin sejak mereka terdatar sebagai peserta PKH cukup meningkat.

Pelaksanaan PKH di Kecamatan Padalarang telah sesuai yang diharapkan yakni dengan adanya bantuan dari PKH telah mampu meningkat kondisi ekonomi peserta $\mathrm{PKH}$, karena dengan adanya bantuan dari PKH masyarakat miskin peserta $\mathrm{PKH}$ bisa menggunakan dana bantuan untuk fasilitas pendidikan serta kesehatan, misalnya seragam sekolah, susu bayi, dan lain sebagainya. Selain itu, PKH memberikan pembekalan mengenai pengelolaan keuangan baik serta cara memanfaatkan potensi diri yang peserta $\mathrm{PKH}$ miliki dan para pendamping selalu menyarankan kepada peserta $\mathrm{PKH}$.

\section{Ketepatan Sasaran}

Sasaran merupakan penjabaran dari tujuan yang menggambarkan suatu yang akan dicapai. Penentuan sasaran yang tepat baik yang ditetapkan secara indvidu maupun sasaran yang ditetapkan organisasi sesungguhnya sangat menentukan keberhasilan aktivitas organasasi. Demikian pula sebaliknya, jika sasaran yang ditetapkan itu kurang tepat, maka akan menghambat pelaksanaan berbagai kegiatan itu sendiri.

Dalam hal ketepatan sasaran dilihat dari ketepatan dalam menentukan masyarakat penerima manfaat PKH. Dalam pelaksanaan $\mathrm{PKH}$, Kepesertaan PKH ditetapkan oleh pusat yang kemudian datanya diberikan kepada pihak kabupaten untuk selanjutnya diberikan kepada pihak kecamatan, data yang diperoleh pusat sebagai acuan penentuan peserta PKH di dapat dari data BPS. Berdasarkan hasil wawancara dengan Kepala UPPKH Kabupaten Bandung Barat dan Kepala Koordinator Pendamping PKH Kecamatan Padalarang Kepesertaan PKH telah ditetapkan oleh pihak pusat dan data acuan yang dipergunakan pusat biasanya dari BPS beberapa tahun sebelumnya sehingga tidak sesuai dengan kondisi masyarakat saat ini. Data BPS tersebut mempunyai waktu yang lama dengan pemeberian PKH tersebut sehingga data dari BPS tersebut tidak sesuai lagi dengan kondisi dilapangan. Terkadang ada 
masyarakat yang tidak masuk pada kriteria peserta $\mathrm{PKH}$ tetapi ia terdaftar sebagai peserta $\mathrm{PKH}$, begitu juga sebaliknya.

Berdasarkan hasil observasi di lapangan peneliti di Kecamatan Padalarang masih belum tepat sasaran dalam memberikan bantuan kepada masyarakat miskin, Masyarakat dengan kalangan menengah ke atas masih ada yang menerima bantuan tersebut, sehingga adanya kecemburuan sosial oleh masyarakat miskin yang tidak mendapatkan bantuan tersebut.

Jika dilihat dari pembahasan di atas, dalam pelaksanaan Program Keluarga Harapan di Kecamatan Padalarang Kabupaten Bandung Barat ini terdapat hambatan-hambatan, dan mengakibatkan kurang optimalnya program yang ada. Hambatan-hambatan tersebut dapat diatasi dengan beberapa cara seperti:

a. Memastikan waktu penerimaan dana PKH

Waktu penerimaan dana PKH seharusnya sesuai dengan waktu yang telah ditetapkan. Pemerintah Kecamatan dengan Koordinator pendamping $\mathrm{PKH}$ telah mengajukan komplain mengenai keterlambatan pencairan dana $\mathrm{PKH}$ yang terjadi di Kecamatan Padalarang.

b. Pendampingan pada saat pencairan dana PKH

Proses pendampingan pada saat pencairan dana $\mathrm{PKH}$ dilakukan untuk menghemat waktu dan membantu peserta PKH dalam mencairkan dana bantuan, karena peserta PKH yang tidak terbiasa sehingga harus didampingi oleh pendamping agar tidak ada kesalahan.

c. Biaya akomodasi yang diberikan kepada pendamping haruslah sesuai Keluhan yang serig disampaikan oleh pendamping PKH kepada koordinator pendamping PKH adalah mengenai biaya akomodasi yang tidak sesuai, sehingga seringkali pendamping PKH menggunakan dana pribadi mereka untuk biaya akomodasi yang diberikan pemerintah kepada pendamping, Koordinator PKH telah menyampaikan keluhan ini kepada UPPKH kabupaten untuk selanjutnya disampaikan pada pihak pusat. 
d. Sosialisasi mengenai kewajiban PKH lebih diperhatikan

Pendamping PKH lebih sering melakukan sosialisasi kepada peserta $\mathrm{PKH}$, dan lebih menekankan tentang begitu pentingnya menyekolahkan anakanaknya dan memeriksakan kesehatan anak-anak mereka ke fasilitas kesehatan terdekat. Hal itu selain sebagai kewajiban mereka sebagai peserta $\mathrm{PKH}$, penting pula bagi masa depan anak-anaknya peserta PKH. 


\section{KESIMPULAN}

Berdasarkan hasil dan pembahasan di atas, dapat disimpulkan bahwa Efektivitas Program Keluarga Harapan dalam Upaya Pengentasan Kemiskinan di Kecamatan Padalarang Kabupaten Bandung Barat belum efektif dikarenakan waktu pemberian dana $\mathrm{PKH}$ yang tidak konsisten terhadap waktu yang telah ditentukan, dana yang diterima peserta PKH tidak sesuai dengan keadaan $\mathrm{PKH}$, serta dana akomodasi yang diterima pendamping tidak sesuai dengan jumlah dana akomodasi yang harus dikeluarkan oleh pendamping $\mathrm{PKH}$, tanggung jawab kecamatan dalam menyediakan infrastruktur untuk menunjang pelaksanaan PKH masih kurang, kurang tegasnya sanksi yang diberikan kepada peserta PKH yang tidak melaksanakan kewajibannya, kecemburuan sosial yang terjadi antara RTSM peserta PKH dengan RTSM yang bukan merupakan peserta PKH, serta kurang tegasnya sanksi yang diberikan pendamping kepada peserta PKH yang tidak melaksanakan kewajibannya.

\section{DAFTAR PUSTAKA}

Arikunto, S. (2010). Prosedur penelitian suatu pendekatan praktik. Jakarta: Rineka Cipta.

Direktorat Jaminan Kesejahteraan Sosial. (2008). Pedoman Operasional Kelembagaan PKH.

Handayaningrat, S. (1994). Pengantar Ilmu Administrasi dan Manajemen. Jakarta: CV Masaagung.

Kementrian Sosial RI. (2007). Pedoman Umum PKH. Jakarta : UPPKH Pusat.

Kurniawan, A. (2005). Transformasi pelayanan publik. Yogyakarta: Pembaharuan.

Makmur. (2015). Efektivitas kebijakan kelembagaan publik. Yogyakarta: Refika Aditama

Moleong, L. (2007). Metodologi penelitian kualitatif. Bandung: PT.Remaja Rosdakarya. 
Retnami, S. (2001). Makalah sistem pemerintahan daerah di indonesia. Jakarta: Kantor menteri Negara Otonomi Daerah Republik Indonesia.

Richard, H. (2006). Implementasi manajemen stratejik kebijakan dan proses. Yogyakarta: Amara Books.

Sugiyono. (2014). Metode Penelitian Kualitatif. Bandung: Alfabeta

Undang-Undang No. 23 Tahun 2014 tentang Pemerintahan Daerah 